\title{
Modulation of Muscle Growth Related Genes in Fish in Response to Plant Based Ingredients
}

\author{
Christian Larbi Ayisi ${ }^{1, *}\left(\mathbb{D}\right.$, Gyamfua Afriyie ${ }^{2}$, Gilbert Owusu-Afriyie ${ }^{3,4,5}$
}

\begin{abstract}
${ }^{1}$ University of Environment and Sustainable Development, School of Sustainable Development, Department of Water Resources and Sustainable Development, Somanya, Eastern Region, Ghana.

${ }^{2}$ Guangdong Ocean University, Fisheries College, Key Laboratory of Aquaculture in South China Sea for Aquatic Economic Animal of Guangdong Higher Education Institutes, Zhanjiang, China.

${ }^{3}$ Shanghai Ocean University, Ministry of Education, Key Laboratory of Exploration and Utilization of Aquatic Genetic Resources, Shanghai 201306, China.

${ }^{4}$ Shanghai Ocean University, Shanghai Engineering Research Center of Aquaculture, Shanghai 201306, China.

${ }^{5}$ Shanghai Ocean University, National Demonstration Center for Experimental Fisheries Science Education, Shanghai 201306, China.
\end{abstract}

\section{How to cite}

Ayisi, C.L., Afriyie, G., Owusu-Afriyie, G. (2022). Modulation of Muscle Growth Related Genes in Fish in Response to Plant Based Ingredients. Genetics of Aquatic Organisms, 6(1), GA413. http://doi.org/10.4194/GA413

\section{Article History}

Received 12 April 2021

Accepted 04 December 2021

First Online 06 December 2021

\section{Corresponding Author}

Tel.: +233247458357

E-mail: aclarbi@uesd.edu.gh

\section{Keywords}

Growth hormone

Insulin-like growth factors

Muscle growth

Hypertrophy

Plant based ingredients

\begin{abstract}
Fish meal and fish oil have been the mostly used ingredients (protein and lipid respectively) in aquaculture feeds due to their excellent source of well-balanced amino acid profile and n-3 long chain polyunsaturated fatty acids (LC-PUFA) respectively. However, due to escalating prices and fluctuation in production, there are calls for alternative protein and lipid sources to be used. Plant based ingredients have been recognized as alternatives that could enhance growth performance as well as reduction in cost of production. The regulation of muscle growth by plant based lipids and protein is not fully elucidated. Growth performance and muscle growth of fish is affected by diets. Acceleration of growth through alteration of genes by diets can be useful as it can reduce cost and decrease time of production. The objective of this review is to discuss the genes that affect muscle growth of fish and how plant based ingredients affect these genes.
\end{abstract}

\section{Introduction}

Due to the desirable nutritional characteristics of fish oil and fish meal, they have been the main sources of lipids and protein respectively in aqua feeds. Fish meal and fish oil are derivatives of marine pelagic fishes (Perez-Velazquez et al., 2019). Fish meal has been recognized as the major protein source due to its abundance of essential nutrients, growth factors and well-balanced amino acid profile (Benjakul et al., 2014, Egerton, 2020). Similarly, fish oil has been a major lipid source due to its abundant essential polyunsaturated fatty acid (PUFA), especially high unsaturated fatty acid (HUFA) (Sargent et al., 2002).
Despite the above-mentioned attributes of fish meal and fish oil, there are calls for these essential nutrients to be replaced due to their higher prices and fluctuation or decline in production. Several researchers (Takakuwa et al., 2006; Zhang et al., 2020; Xu et al., 2020; Arriaga-Hernández et al., 2021) have reported that plant based protein are suitable to replace fish meal whilst other researchers (Izquierdo et al., 2005; Montero et al., 2005) have confirmed that plant based oils are suitable replacements for fish oil. These studies have predominantly assessed how the alternative nutrients affect growth and nutrient utilization with an emerging interest on how they affect lipid deposition in the liver and other tissues. In addition, some studies 
have analyzed how plant ingredients affect growth related genes.

The extent of protein deposition which is directly dependent upon the balance between synthesis of protein and its degradation affects growth of fish (Tu et al., 2015). Satellite cells and myoblasts (myogenic precursor cells) are important in proliferation and differentiation processes that affect growth of muscle in fish (Rowlerson \& Veggetti, 2001). Whereas primary myogenic regulatory transcription factors (myod and myf5) directly work on myogenic progenitor proliferation towards a myogenic lineage, secondary myogenic regulatory transcription factors (myf5 and myogenin) act on myoblast differentiation and fusion to form muscle fibers (Megeney \& Rudnicki, 1995). The aim of these molecular pathways is to strike a balance between positive and negative muscular signals in a dynamic way (Johnston, 2006).

In this review, the effects of plant based ingredients on genetic make-up of different fish species with special focus on muscle growth related genes.

\section{Stages of Muscle Growth in Fish}

Most fishes continue to grow throughout their lives. Growth in fish has been studied intensively because it is a good indicator of health. Rapid growth indicates abundance of food and other favorable conditions, whereas slow growth is likely to indicate just the opposite. Growth is commonly measured as changes in body weight, length or condition factor (i.e. weight/ length relationship) over time. Post-embryonic growth of the muscle tissue involves an increase in the number and diameter of the fibres and a contemporary remodeling of the associated connective tissue, nerve and blood supply.

Growth is usually positive, in that the fish increase in size over time. The principal factors controlling the growth processes are growth hormones secreted by the pituitary and steroid hormones from the gonads. However, the rate of growth of fish is highly variable because is it greatly dependent on a variety of interacting environmental factors such as water temperature, levels of dissolved oxygen and ammonia, salinity and the photoperiod (Moyle \& Cech, 1982). Such factors interact with each other to influence growth rates. Others include the degree of competition, the amount and quality of food ingested, and the age and state of the maturity of the fish. In this section, the two main types of muscle growth in fish namely hypertrophy and hyperplasia are discussed.

\section{Hypertrophy}

In fish, the muscle grows by enlargement of existing fibres (hypertrophy) throughout postembryonic life until they reach a functional maximum diameter, which is in the range 100-300 $\mu \mathrm{m}$ for white fibres in most fish (Rowlerson \& Vegetti, 2001).
Hypertrophic growth persists long after hyperplastic growth has ceased (e.g. Stickland, 1983, Rowlerson \& Vegetti, 2001). As the fibres increase in size they get packed with myofibrils. Fibres also acquire additional nuclei as they grow (Johnston, 1993). The new nuclei are supplied by a population of satellite cells (already present in the muscle), which fuse with existing muscle fibres to provide the additional nuclei (Johnston, 2001). To supply the number of nuclei required during growth, this population must be capable of proliferation. In fish, a major uncertainty is whether there are separate muscle stem cell populations for fibre recruitment and fibre hypertrophy.

\section{Hyperplasia}

Hyperplastic growth of muscle refers to the increase in muscle fibre number due to the formation of new fibres. After the initial two muscle layers have been formed during embryonic life, hyperplastic growth continuous in two successive and distinct phases. The first phase is a continuation of embryonic myogenesis which completes the formation of the definitive muscle layers (slow red, pink and fast white), followed by a second and quite different hyperplastic process resulting in a large increase in the total number of fibres in all muscle layers, especially in the white muscle layer (Rowlerson \& Vegetti, 2001). New presumptive fast white fibres during embryonic and into larval life, appear in a germinal layer or proliferation zone located just under the superficial mono layer and extends dorsally from the horizontal septum into the apex of the myotome. In many fish species which remain small, this second hyperplastic growth phase is lacking, whereas fast-growing fish generally show greater hyperplasia than slow-growing fish of the same age (Weatherley et al., 1979; Weatherley \& Gill, 1984; Higgins \& Thorpe, 1990). In most fishes which grow to a large final size, the majority of muscle fibres are formed in a long-lasting hyperplastic growth process disseminated throughout the entire myotome. This process gives rise to the typical mosaic appearance of muscle cut in transverse section, with fibres of different ages (and therefore diameter) intermingled. Mosaic hyperplastic muscle growth, which occurs principally during juvenile life, is of great interest in commercial aquaculture because it contributes to the market size of the fish. The intensity of mosaic hyperplastic growth is most pronounced in early juvenile life: later it decreases gradually until the fish reaches a characteristic fraction of body size after which further growth occurs by hypertrophy only (Weatherley et al., 1988; Stickland, 1983). There is indirect evidence for the existence of a distinct population of myogenic cells supporting mosaic hyperplastic growth (Rowlerson \& Vegetti, 2001)

In conclusion; muscle fibre growth in fish consists of two distinct phases. The first during early larvae age, comparable to that seen in higher vertebrates during the embryonic stage, and a second during adult life 
signified by a combined hyperplasia and hypertrophy. Growths during both these stages are under a combined genetic and environmental control. The relationship between final muscle fibre composition and size has long been debated but only recently the target for systematic research. An undeniable relationship exist, however, the predictive power is weak using the fibre component alone. Based on available data the degree of explanation varies from 0 - $25 \%$ depending on species, life stage and variable studied. The majority of variation measured in quality of the fish fillet is probably an effect of the connective tissue, the lipid component and naturally also to handling of the flesh post mortem.

\section{Growth Related Genes}

Muscle growth mechanisms are controlled by different cellular and molecular pathways, and dietary lipids may play an important role to influence such pathways in fish. Growth of fish is mostly dependent upon the growth of muscles. Basically, growth of muscle occurs as a result of hyperplasia and hypertrophy. Hyperplasia is the recruitment of new muscle fibres whiles hypertrophy is the expansion of existing muscles.

Stratified hyperplasia and mosaic hyperplasia are the two distinct phases of hyperplasia observed in different aquaculture fish species. In stratified hyperplasia, new muscle fibres that are formed are restricted to the germinal zones only whiles in mosaic hyperplasia, the fibre muscles are formed throughout the myotome (Md. Asaduzzaman et al., 2017).

Several genetic factors control/ regulate muscle growth in fish being it growth via hypertrophy or hyperplasia. These include growth hormone (GH), insulin-like growth factors (IGFs), myogenic regulatory factors (MRFs), paired box proteins (Paxs) and myostatin (Johnston et al., 2009). Other genes such as transforming growth factor- $\beta$ (TGF- $\beta$ ) and Myf5 are known to play essential roles in muscle growth. The functions of these genes are briefly discussed below.

\section{Insulin-like Growth Factors}

IGF-I and IGF-II, as well as their receptors and binding proteins are the major components of the IGF system. IGF-I and IGF-II are the mitogenic peptides, which are regulated by the nutritional status of fish. IGFs play important roles which includes somatic growth, development and functional maturation of the central nervous system (CNS), skeletal tissues, and reproductive organs (Duan et al., 2010). Myocyte hypertrophy during regeneration of muscles, proliferation and differentiation of muscle precursor cells (myoblast or satellite cells) as well as growth stimulation are controlled by Insulin-like growth factors (Florini et al., 1996; Musaro et al., 1999; Terova et al., 2007). IGF-I, is basically produced or synthesized in the liver and serve as an anabolic agent for growth of tissues.
Figure 1 shows how growth of fish muscle and atrophy is controlled by the IGF axis via the mTOR/Akt/P70S6K signaling as previously described by Johnston et al. (2008).

Several intracellular kinases such as phosphatidylinositol-3-kinase (PI3K) are activated when a membrane receptor is bounded by IGF-I

$\mathrm{PI3K}$ provides a binding site for lipid on membranes for serine/threonine kinase known as Akt as a result of the presence of PI3K phosphorylates the membrane phospholipids phoshatidylinositol-4,5-bis-phosphate to phoshatidylinositol-3, 4,5-trisphosphate. Akt is translocated to the membrane which facilitates its activation by PDK-I as well as its phosphorylation. One other function of the IGF-I/PI3K/Akt signaling pathway is to switch between the synthesis of protein and degradation by reducing catabolic pathways through the inhibition of the FoxO family of transcription factors which prevent induction of the muscle-specific ubiquitin ligases MAFbx and MuRF-I.

\section{Growth Hormone (GH)}

Several functions of fish are affected by growth hormones (GH). These include energy metabolism, feeding, reproduction, immune function as well as somatic growth (Chang and Wong, 2009). The GH is the main regulator that controls somatic growth in vertebrates (LeRoith et al., 2001; Björnsson et al., 2002). The $\mathrm{GH}$ affects muscle growth in fish through controlling muscle hypertrophy and hyperplasia (Fuentes et al., 2013). GH is linked with somatic growth and is secreted by the pituitary glands (Reinecke et al. 2005). The endocrine system controls growth in fish and this occurs through the growth hormone-insulin-like growth factor axis (Picha et al., 2008).

\section{Paired Box Proteins-7 (Pax-7)}

The Paired box proteins-7 (Pax-7) is expressed in mono-nucleated proliferating myogenic cells. Its transcription factor is expressed in satellite cells in vertebrates of which fish is included. Its important role in the regulation of skeletal muscle growth as well as its regeneration (Chapalamadugu et al., 2015) are phenomenal. Pax-7 is important during development of the skeletal muscle (Ziman et al., 2001). Muscle progenitors and satellite cells which contribute to the proliferation of myogenic cells during secondary myogenesis are controlled by Pax-7. According to Kacperczyk et al., (2009), Pax-7 is a developmental gene that plays essential role during hypertrophic and hyperplastic muscle growth. Furthermore, Pax-7 positive cells differentiate into myosatellite cells after the cells migrate into the myotomes (Kacperczyk et al., 2009). 


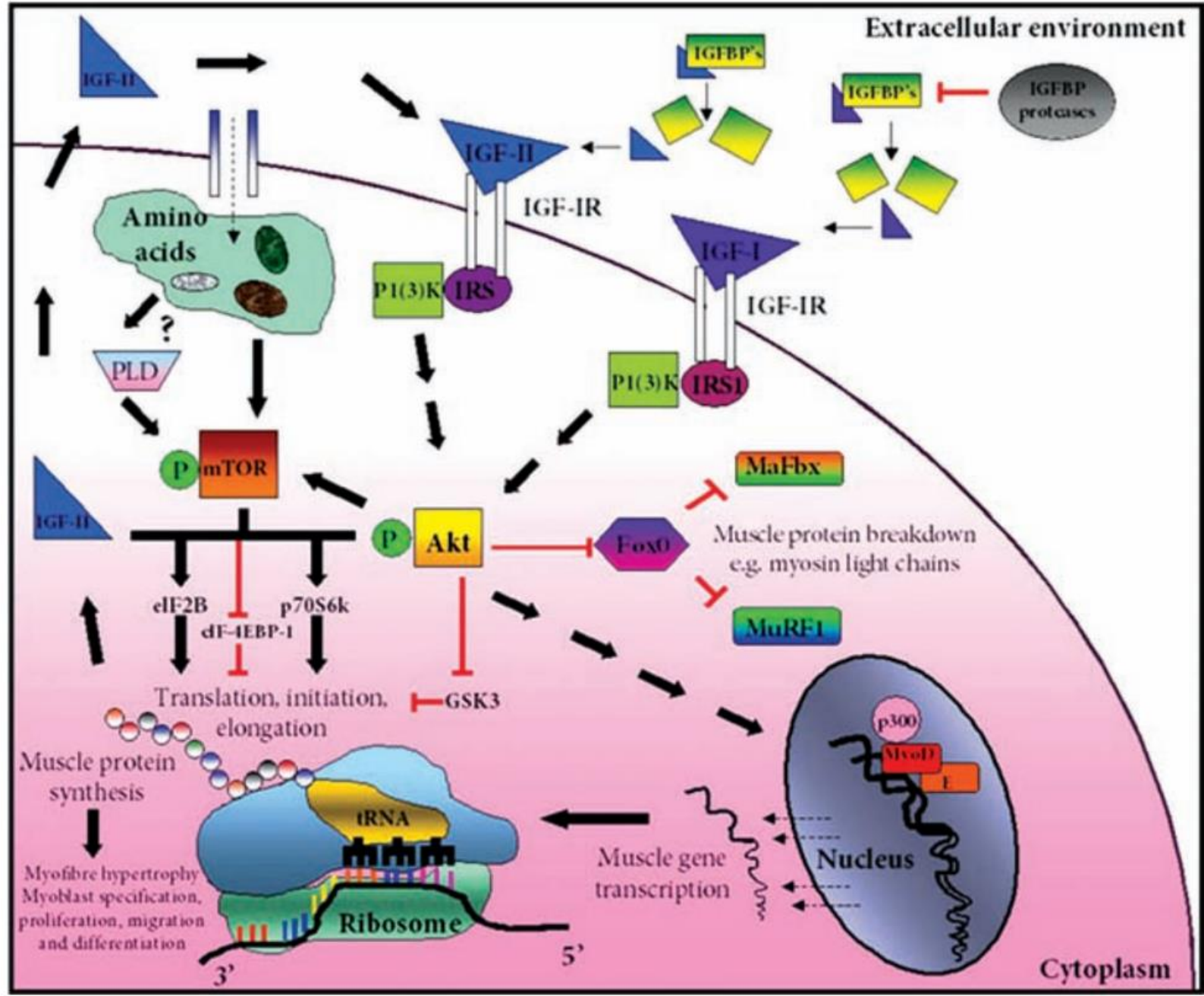

Figure 1. A Schematic representation of the IGF axis regulating muscle growth and atrophy via the mTOR/Akt/P70S6K signaling cascade (Adopted from Johnston et al 2008).

\section{Calpain (Capn)}

Calpains (Capn) are heterodimers with two subunits. The first unit is made up of a large $80 \mathrm{kDa}$ catalytic subunit whiles the second is made up of a small $30 \mathrm{kDa}$ regulatory subunit (Preziosa et al., 2013). Generally, the functions of Capn include but not limited to regulation of cell motility (Glading et al., 2002), cell death apoptosis (Liu et al., 2004) along with muscle atrophy (Richard et al., 1995) and myoblast fusion (Honda et al., 2008). Calpain-3 also known as nCL-1 or p94 is a proteasome enzyme known to possess a very high autolytic activity (Ono et al., 2016). They are $\mathrm{Ca}^{2+}$ dependent.

\section{Myogenin (MyoG)}

Myogenin (MyoG) is a basic helix-loop-helix transcription factors which is a member of muscle regulatory factor (MRF) gene family. According to Tan et al. (2002), MyoG is responsible for regulating development of skeletal muscle together with its growth. MyoG plays a crucial role in the differentiation of muscle precursor cells (Burgerhout et al., 2017). It also controls the proliferation and terminal differentiation of myoblasts (Buckingham \& Rigby, 2014) as well as differentiation of myocytes (Bergstrom \& Tapscott, 2001)

\section{Myoblast Determining Factor (MyoD)}

Myoblast determining factor (MyoD) is one of the helix-loop-helix proteins that controls the expression of genes in the muscle of fish including tilapia. The activation and proliferation of satellite cells are regulated by MyoD (Watabe, 2001). MyoD is known to function during the initial stages of myocytes by initiating myogenic determination (Arnold \& Winter, 1998). In many teleost species, MyoD expressions generally occur before segmentation in adaxial cells (Temple et al., 2001)

\section{Proteasomes}

The proteasomes are a barrel-shaped intracellular multicatalytic protease responsible for a highly controlled degradation of target proteins (Jung et al., 
2001). It regulates proteins through a mechanism of selective degradation (Pagano et al., 1995; Tokumoto et al., 1997). Mitotic and meiotic cells are regulated by proteasomes (Tokumoto, 1999). Changes in the localization of proteasomes influence cell cycles.

\section{Myostatin (MSTN)}

Myostatin (MSTN) is a member of the transforming growth factor family $\beta$ (TGF- $\beta$ ). MSTN is also called growth differentiation factor (GDF-8). It plays essential roles such as growth and differentiation of muscle in fish. It performs this function by regulating negatively the cycle of cells in tissues (McPherron et al., 1997). MSTN consist of three exons with approximated size of 300 - 400 nucleotides separated by two introns, with a highly conserved structure (Gabillard et al., 2013).

\section{Myocyte Enhancer Binding Factor (Mef)}

Myocyte enhancer (ME) transcription dynamics are members of the MADS (MCM1-agamous-deficiensserum response factor) family of transcription factors (Naya \& Olson, 1999). They are important genes that regulate the development of phenotypes of different tissues in adult organisms. Such tissues include skeletal and cardiac muscles. Mefs such as Mef-2 plays key role in the development and adaptation in postnatal to a wide array of physiological and pathological signals. In addition, they play essential role in the neurons, lymphocytes and myocytes by controlling the expression of genes (Ma et al., 2005).

\section{Cathepsin}

Cathepsins belong to the cysteine and aspartic proteases family that are characterized by the specificity of their structure and substrate. They are found in lysosomes and perform at low $\mathrm{pH}$. Cathepsins have been reported to perform an important function in cellular turnover and bone resorption (Yasuda et al., 2005).

Cathepsins are acid proteases located in the lysosomes. They may be liberated into both the cytoplasm and the intracellular spaces as a consequence of lysosomal disruption occurring after cell death due to a $\mathrm{pH}$ fall (Duston, 1983).

\section{Calpastatin}

Calpastatin (CAST) is a specific endogenous inhibitor of the calcium-dependent neutral proteases, calpains (Goll et al., 1992). The formation of muscle fibers, reorganization of the cytoskeleton and promotion of myoblast fusion are important roles performed by CAST (Cottin et al., 1994; Temm-Grove et al., 1999). Other important roles of CAST include growth of muscle and meat quality enhancement (Salem et al., 2005).
Effects of Plant Based Nutrients on Expression of Muscle Growth Related Genes

\section{Effects of Plant Based Proteins on Expression of Muscle Growth Related Genes}

There has been an increase in the market price of fish meal to almost $300 \%$ in the past ten years. This could be attributed to high demand for fish meal as a result of rapid development in aquaculture as well as fishing restrictions. This phenomenon has led to call for alternative protein sources that are sustainable to be used in aquaculture. In answering this call, several studies have been conducted in search of suitable alternatives. In this section, we critically review the effects of some plant based protein in fish focusing on expression of genes related to growth.

Ulloa et al., (2013) studied the effects of a plant protein (PP) and fishmeal-based diets on growth response in a population of 24 families, as well as expression of growth-related genes in the muscle of adult zebrafish (Danio rerio). At 98dpf, growth-related genes (Igf1a, Igf2a, mTOR, Pld1a, Mrf4, Myod, Myogenin, and Myostatin1b) were evaluated. In males, Myogenin, Mrf4, and Igf2a showed changes attributable to the PP diet. In females, the effect of the PP diet did not restrain the expression in any of the eight genes considered. The effect of familiar variation on gene expression was observed among families. This study shows that plant protein diet and family variation have effects on gene expression in fish muscle.

The effects of substituting fish meal with increasing levels of plant protein blends on expression levels in the Senegalese sole were studied by Valente et al., (2015). The fish were fed four diets with $(54 \%$ protein and $9 \%$ lipid). Three diets (50\% PP50, 75\% PP75 and 100\% PP100) were compared to a control fish meal-based diet (FM). The observed changes in muscle cellularity could not be associated with the relative expression levels of texture-related genes [capn2 $(0.8$ to 1.4$)$, ctsb $\left(0.9^{3}\right)$, ctsd (1.0 to 1.2$)$ ] in all diets, since no significant differences were observed among diets. The present results pointed towards a modulation of the expression of several muscle growth related genes by increasing levels of plant protein sources that alter muscle cellularity and textural properties of Senegalese sole when total fish meal is replaced with plant protein.

It was established that using corn gluten meal as a substitute for fish meal does not significantly alter hepatic target of rapamycin (TOR), dorsal muscle IGF-I and TOR expression levels. This was after Luo et al. (2012) had fed cobia (Rachycentron canadum with initial weight $108.2 \pm 3.0 \mathrm{~g}$ with five diets with similar protein and lipid contents (isonitrogenous (crude protein 45\%) and isoenergetic (gross energy $20 \mathrm{~kJ} \mathrm{~g}^{-1}$ respectively). The control diet which had only fish meal was substituted with corn gluten meal at $17.5 \%, 35.0 \%$, $52.5 \%$, and $70.0 \%$. 
Similarly, Men et al., (2014) substituted fish meal with corn gluten meal (CGM) to study its influence on expression levels of IGF-I in Japanese seabass (initial body weight $18.09 \pm 0.10 \mathrm{~g}$ ). Six isonitrogenous (crude protein $43 \%$ ) and isoenergetic (18 kJ g-1) practical diets were formulated by replacing 0 (the control), 15, 30, 45, 60 and $75 \%$ of fish meal protein with CGM protein. In the end, the authors reported a significant decrease in the expression levels of IGF-I when fish were fed diets with $60 \%$ protein from CGM compared to fish fed diets with $100 \%$ protein from fish meal (Control). Their study showed that there was no difference in the IGF-I expression in the muscle tissue.

Table 1 shows the effects of plant based protein on the expression of muscle growth related genes.

\section{Effects of Plant Based Lipids on Expression of Muscle Growth Related Genes}

Lipids play important physiological roles in providing energy, essential fatty acids and fat soluble nutrients for normal growth and development of fish. Deficiency of dietary lipid may increase the use of protein for energy and result in the increase of ammonia excretion and thus water pollution. Plant based lipids have a nutritional advantage over animal fats since they contain a higher portion of unsaturated fatty acids

Plant based lipids have been used as substitute for fish oil due to their cheaper prices, sustainability and their ability to affect growth positively. Some studies have been conducted to evaluate the extent to which these plant based oil sources affect genes that regulate muscle growth.
In 2017, Kutluyer and colleagues evaluated the effects of replacing fish oil with plant oils in diets of Oncorhynchus mykiss. The effects of the experimental diets on growth related genes in muscle were evaluated. In this study, O. mykiss were fed diets containing cod liver oil (CO), safflower seed oil (SSO), soybean oil (SBO) and linseed oil (LO) as single protein sources or in a combination of SBO+LO and SSO and LO. The results showed that fish fed $L O$ and $S B O+L O$ recorded the highest expression level of GH-I mRNA in the muscle. Compared to other treatments, O. mykiss fed SBO recorded the highest level of IGF-II mRNA expression in the muscle whilst IGF-I was however highly expressed in the muscle of fish fed SBO+LO.

The effects of substituting fish oil with plants based oils on relative gene expression of key genes involved in myogenesis as well as muscle growth were assessed in Senegalese sole by Lopes et al. (2017). Rapeseed oil, soybean oil and linseed oil were used in place of fish oil and fed to Senegalese sole (initial weight $152 \mathrm{~g} \pm 18$ ) over 140 days period. The results showed no significant difference in relative mRNA expression of myosin superfamily elements as well as myhc and mylc2. Similarly, the expression of mstn1 was non-significantly different irrespective of the diets.

Bertuccia et al., (2018) studied the influence of substituting fish oil with sunflower oil in diets of pejerrey fry on expression of genes involved in somatic growth. Fish oil was substituted with sunflower at 0\%, 50\%, 80\% and $100 \%$ and fed to pejerrey fry over 45 days. The results showed that mRNA expression levels of $\mathrm{GH}$, ghrI and ghr-II were higher in head and trunk of fry fed diets with $100 \%$ sunflower. Compared to group fed diet with

Table 1. Effects of plant based protein on modulation of muscle growth related genes and growth performance

\begin{tabular}{|c|c|c|c|c|c|c|}
\hline $\begin{array}{l}\text { Plant-based } \\
\text { protein }\end{array}$ & Species & $\begin{array}{l}\text { Initial } \\
\text { weight } \\
\text { (g) }\end{array}$ & Gene name(s) & $\begin{array}{l}\text { Modulation (up } \\
\text { or down vs } \\
\text { control) }\end{array}$ & $\begin{array}{l}\text { Observation on growth } \\
\text { performance }\end{array}$ & References \\
\hline $\begin{array}{l}\text { Soybean meal, } \\
\text { peas, corn } \\
\text { gluten, and } \\
\text { wheat }\end{array}$ & Senegalese sole & 106 & $\begin{array}{l}\text { mrf4, fgf6, } \\
\text { myhc and } \\
\text { mylc2 }\end{array}$ & Down regulation & $\begin{array}{l}\text { Increasing plant protein } \\
\text { reduced growth } \\
\text { performance. }\end{array}$ & $\begin{array}{l}\text { Valente et } \\
\text { al., } 2015\end{array}$ \\
\hline Soy bean & Danio rerio & 0.214 & $\begin{array}{c}\text { Mylpfb } \\
\text { hsp90aa1.1 } \\
\text { col2a1a } \\
\text { odc1 }\end{array}$ & Up regulated & $\begin{array}{l}\text { Improved muscle } \\
\text { development }\end{array}$ & $\begin{array}{c}\text { Dhanasiri et } \\
\text { al., } 2020\end{array}$ \\
\hline Soybean meal & Danio rerio & NA & $\begin{array}{l}\text { Myogenin, } \\
\text { Mrf4, and } \\
\text { Igf2a }\end{array}$ & Up regulated & $\begin{array}{l}\text { Increased fish muscle } \\
\text { formation }\end{array}$ & $\begin{array}{l}\text { Ulloa et al., } \\
2013\end{array}$ \\
\hline Soybean meal & $\begin{array}{c}\text { Dicentrarchus } \\
\text { labrax }\end{array}$ & NA & $\begin{array}{c}\text { CCT2 } \\
\text { EIF4G1 } \\
\text { KIAA2018 } \\
\text { MRPL22 }\end{array}$ & Up regulated & Improved growth & $\begin{array}{c}\text { Geay et al., } \\
2011\end{array}$ \\
\hline $\begin{array}{l}\text { Corn gluten } \\
\text { meal }\end{array}$ & $\begin{array}{l}\text { Rachycentron } \\
\text { canadum }\end{array}$ & 108.2 & IGF-I and TOR & Unaffected & $\begin{array}{l}\text { Higher levels of corn } \\
\text { gluten meal reduced } \\
\text { growth performance }\end{array}$ & $\begin{array}{l}\text { Luo et al., } \\
2012\end{array}$ \\
\hline $\begin{array}{l}\text { Corn gluten } \\
\text { meal }\end{array}$ & $\begin{array}{l}\text { Lateolabrax } \\
\text { japonicus }\end{array}$ & 18.09 & IGF-I & Down regulation & $\begin{array}{l}\text { Growth performance } \\
\text { decreased as corn } \\
\text { gluten meal increased }\end{array}$ & $\begin{array}{c}\text { Men et al., } \\
2014\end{array}$ \\
\hline
\end{tabular}


$100 \%$ fish oil, there was significantly higher expression of IGF-II in trunk of fry fed with $100 \%$ sunflower oil.

\section{Conclusion}

In this review, it has been established that plant based protein and lipids have different effects on regulation of growth related genes via; insulin-like growth factors, growth hormone, paired box proteins, calpain, myogenin, myoblast determining factor, proteasomes, myostatin, myocyte enhaner binding factor, cathespsin and calpastatin among others. This review recommends that more studies should be done towards the effect of plant based lipids and protein on the expression of genes that modulate growth.

\section{Author Contribution}

CLA: Conceived idea, drafted initial manuscript, Revised manuscript, Provided information. GA: Drafted initial manuscript, Revised manuscript, Provided information. GO-A: Drafted initial manuscript, Provided information.

\section{Conflict of Interest}

The author(s) declare that they have no known competing financial or non-financial, professional, or personal conflicts that could have appeared to influence the work reported in this paper.

\section{References}

Ahmed, M., Liang, H., Chisomo, H., Ke, K., Xianping, J., Liu, B., Zhu, X., \& Sun, A. (2018). Complete replacement of fish meal by plant protein ingredients with dietary essential amino acids supplementation for juvenile blunt snout bream (Megalobrama amblycephala). Aquaculture Nutrition, 25(1), 205-214, https://doi.org/10.1111/anu.12844

Arnold, H.H., \& Winter, B. (1998). Muscle differentiation: more complexity to the network of myogenic regulators. Curr Opin Genet Dev. 8, 539-544.

Arriaga-Hernández, D., Hernández, C., Martínez-Montaño, E., Ibarra-Castro, L., Lizárraga-Velázquez, E., Leyva-López, N., \& Chávez-Sánchez, M.C. (2021). Fish meal replacement by soybean products in aquaculture feeds for white snook, Centropomus viridis: Effect on growth, diet digestibility, and digestive capacity. Aquaculture, 530, 735823.

Benjakul, S., Yarnpakdee, S., Senphan, T., Halldorsdottir, S.M. \& Kristinsson, H. G. (2014). Fish protein hydrolysates: production, bioactivities and applications. Antioxidants and functional components in aquatic foods, 1st ed. Reykjavik, Iceland: Matil Ltd, 237Á283

Bergstrom, D.A., \& Tapscott, S.J. (2011). Molecular distinction between specification and differentiation in the myogenic basic helix-loop-helix transcription factor family. Mol Cell Biol. 21, 404-412.

Bertucci, J.I., Tovar, M.O., Unniappan, S., Navarro, J.C., \& Canosa, L.F. (2018). Effects of dietary sunflower oil on growth parameters, fatty acid profiles and expression of genes regulating growth and metabolism in the pejerrey (Odontesthes bonariensis) fry. Aquaculture Nutrition, 24(2), 748-757

Bertucci, J.I., Tovar, M.O., Unniappan, S., Navarro, J, C., \& Canosa, LF. (2018). Effects of dietary sunflower oil on growth parameters, fatty acid profiles and expression of genes regulating growth and metabolism in the pejerrey (Odontesthes bonariensis) fry. Aquacult Nutr. 24, 748757. https://doi.org/10.1111/anu.12603

Björnsson, B.Th., Johansson, V., Benedet, S., Einarsdottir, I.E., Hildahl, J., Agustsson, T., Jönsson, E. (2002). Growth hormone endocrinology of salmonids: regulatory mechanisms and mode of action. Fish Physiol. Biochem. 27, 227-242.

Buckingham, M., \& Rigby, P.W.J. (2014). Gene Regulatory Networks and Transcriptional Mechanisms that Contro Myogenesis. Developmental Cell, 28(3), 225-238.

Burgerhout, E., Mommens, M., Johnsen, H., Aunsmo, A., Santi, N., \& Andersen, $\varnothing$. (2017). Genetic background and embryonic temperature affect DNA methylation and expression of myogenin and muscle development in Atlantic salmon (Salmo salar). PLoS ONE 12(6): e0179918.

https://doi.org/10.1371/journal.pone.0179918

Chang, J.P., \& Wong, A.O.L. (2009). Chapter 4 Growth Hormone Regulation in Fish. Fish Neuroendocrinology, 151-195. https://doi:10.1016/s1546-5098(09)28004-6

Chapalamadugu, K.C., Murdoch, B.M., Robison, B.D., Rodney AH., \& Gordon K Murdoch (2015). Oncorhynchus mykiss pax7 sequence variations with comparative analyses against other teleost species. SpringerPlus 4, 263.

Cottin, P., Brustis, J.J., \& Poussard, S. (1994). Ca2+-dependent proteinases (calpains) and muscle cell differentiation, Biochim. Biophys. Acta, 1223, 170-178.

Dhanasiri, A.K.S., Johny, A., Xue, X., Berge, G.M., Bogevik, A.S., Rise, M.L., Fæste, C.K., \& Fernandes, J.M.O. (2020). Plant-Based Diets Induce Transcriptomic Changes in Muscle of Zebrafish and Atlantic Salmon. Frontiers in Genetics, 11, 1-15. https://doi.org/10.3389/fgene.2020.575237

Duan, C., Ren, H., Gao, S. (2010). Insulin-like growth factors (IGFs), IGF receptors, and IGF-binding proteins: roles in skeletal muscle growth and differentiation. Gen. Comp. Endocrinol, 167, 344-351.

Duston, T. R. (1983). Relationship of $\mathrm{pH}$ and temperature to disruption of specific muscle proteins and activity of Iysosomal proteases. Journal of Food Biochemistry, 7 , 223-245.

Egerton, S., Wan, A., Murphy, K., Collins, F., Ahern, G., Sugrue, I., Busca, K., Egan, F., Muller, N., Whooley, J., McGinnity, P., \& Cullo S. (2020). Replacing fishmeal with plant protein in Atlantic salmon (Salmo salar) diets by supplementation with fish protein hydrolysate. Scientific Reports, 10, 4194 | https://doi.org/10.1038/s41598020-60325-7

Espe, M., El-mowafi, A., \& Ruohonen, K. (2012). Replacement of Fishmeal with Plant Protein Ingredients in Diets to Atlantic Salmon (Salmo salar) - Effects on Weight Gain and Accretion. In (In Tech Open) Dr. Zainal Muchlisin (Ed.) (Ed.), Aquaculture, 1, 43-58). InTech. http://www.intechopen.com/books/aquaculture/replac ement-of-fishmeal-with-plant-protein-ingredients-indietsto-atlantic-salmon-salmo-salar-effec

Florini, J. R., Ewton, D.Z., \& Coolican, S.A. (1996). Growth hormone and the insulinlike growth factor system in myogenesis. Endocrine Reviews, 17, 481-517. 
Francesco, M.D., Parisi, G., Perez-Sanchez, J., Gomez-Requeni, P., Medale, F., Kaushik, S.J., Mecatti, M., \& Poli, B.M. (2007). Effect of high-level fish meal replacement by plant proteins in gilthead sea bream (Sparus aurata) on growth and body / fillet quality traits. Aquaculture Nutrition, 13, 361-372.

Fuentes, E.N., Valdés, J.A., Molina, A., \& Björnsson, B.T. (2013). Regulation of skeletal muscle growth in fish by the growth hormone - Insulin-like growth factor system. General and Comparative Endocrinology, 192, 136-148. https://doi: 10.1016/j.ygcen.2013.06.009

Fukada, H., Kitagima, R., Shinagawa, J., Morino, H., \& Masumoto, T. (2021). Effects of complete replacement of fish oil with plant oil mixtures and algal meal on growth performance and fatty acid composition in juvenile yellowtail Seriola quinqueradiata. Fisheries Science, 9, 1-12. https://doi.org/10.1007/s12562-01901361-9

Gabillard, J.C., Biga, P.R., Rescan, P.Y., \& Seiliez, I. (2013) Revisiting the paradigm of myostatin in vertebrates: insights from fishes. General comp Endocrinol. 194, 4554.

Geay, F., Ferraresso, S., Zambonino-infante, J. L., Bargelloni, L., Quentel, C., Vandeputte, M., Kaushik, S., Cahu, C. L., \& Mazurais, D. (2011). Effects of the total replacement of fish-based diet with plant-based diet on the hepatic transcriptome of two European sea bass (Dicentrarchus labrax) half-sibfamilies showing different growth rates with the plant-based diet. BMC Genomics. 23, 12:522.

Glading, A., Lauffenburger, D.A., \& Wells, A. (2002). Cutting to the chase: calpain proteases in cell motility. Trends Cell Biol. 12, 46-54

Goll, D.E., Thompson, V.F., Li, H., Wei, W., \& Cong, J. (2003). The calpain system. Physiol. Rev. 83, 731-801.

Higgins, P.J., \& Thorpe, J.E. (1990). Hyperplasia and hypertrophy in the growth of skeletal muscle in juvenile Atlantic salmon, Salmo salar. J. Fish.Biol. 37, 505-519

Honda, M., Masui, F., Kanzawa, N., Tsuchiya, T., \& Toyo-oka T.S. (2008). pecific knockdown of $m$-calpain blocks myogenesis with cDNA deduced from the corresponding RNAi. Am J Physiol Cell Physiol. 294, C957-965.

hypothesis: 2001. Endocr. Rev. 22, 53-74.

Izquierdo, M.S., Montero, D., Robaina, L., Caballero, M.J., Rosenlund, G., \& Gines, R. (2005). Alterations in fillet fatty acid profile and flesh quality in gilthead seaabream (Sparus aurata) fed vegetable oils for a long term period. Recovery of fatty acid profiles by fish oil feeding. Aquaculture, 250, 431-444.

Johnston, I.A. (1993). Temperature influences muscle differentiation and the relative timing of organogenesis in herring (Clupea harengus) larvae. Marine Biology. 116, 363-379

Johnston, I.A., 2006. Environment and plasticity of myogenesis in teleost fish. J. Exp. Biol. 209, 2249-2264. https://doi.org/10.1242/jeb.02153.

Johnston, I.A., Macqueen, D.J, \& Watabe, S. (2008). Molecular biotechnology of development and growth in fish muscle. In Fisheries for Global Welfare and Environment, 5th World Fisheries Congress (ed. K. Tsukamoto, T. Kawamura, T. Takeuchi, T. D. Beard Jr and M. J. Kaiser), pp. 241-262. TERRAPUB: Tokyo.

Jung, T., Catalgol, B., \& Grune, T. (2009). The proteasomal system. Molecular aspects of medicine, 30, 191-296.

Kacperczyk, A., Jagla, T., \& Daczewska, M. (2009). Pax-3 and Pax-7 label muscle progenitor cells during myotomal myogenesis in Coregonus lavaretus (Teleostei: Coregonidae). Anat Histol Embryol., 38, 411-418

Kaushik, S.J., \& Cowey CB. (1991). Dietary factors affecting nitrogen excretion by fish. In: Cowey $\mathrm{CB}$, Cho $\mathrm{CY}$ editors. Nutritional Strategies and Aquaculture Waste. University of Guelph; Canada: pp. 3-19.

Kaushik, S.J., Covès, D., Dutto, G., \& Blanc, D. (2004). Almost total replacement of fish meal by plant protein sources in the diet of a marine teleost, the European seabass, Dicentrarchus labrax. Aquaculture, 230 (1-4), 391-404.

Kutluyer, F., Sirkecioğlu, A.N., Aksakal, E., Aksakal, F.I., Tunç, A., \& Günaydin, E. (2017). Effect of dietary fish oil replacement with plant oils on growth performance and gene expression in juvenile rainbow trout (Oncorhynchus mykiss). Ann. Anim. Sci., 17(4), 1135-1153.

LeRoith, D., Bondy, C., Yakar, S., Liu, J.L., Butler, A. (2001). The somatomedin

Liu, X., Van Vleet, T., \& Schnellmann RG. (2004). The role of calpain in oncotic cell death. Annu Rev Pharmacol Toxicol. 44, 349-370.

Lopes, G., Castro, L. F. C., \& Valente, L.M.P. (2017). Tota substitution of dietary fish oil by vegetable oils stimulates muscle hypertrophic growth in Senegalese sole and the upregulation of fgf6. Food \& function, 8(5), 1869-1879.

Luo, Y., Ai, Q., Mai, K., Zhang, W., Xu, W., Zhang, Y., \& Liufu, Z. (2012). Effects of dietary corn gluten meal on growth performance and protein metabolism in relation to IGF-I and TOR gene expression of juvenile cobia (Rachycentron canadum). J. Ocean Univ. China 12(3), 418-426. https://doi.org/10.1007/s11802-013-2021-3

Ma, K., Chan, J.K., Zhu, G., Wu, Z. (2005). Myocyte enhancer factor 2 acetylation by $\mathrm{p} 300$ enhances its DNA binding activity, transcriptional activity, and myogenic differentiation. Mol. Cell Biol. 25, 3575-3582

McPherron, A.C., Lawler, A.M., \& Lee, S.J. (1997). Regulation of skeletal muscle mass in mice by a new TGF-beta superfamily member. Nature, 387, 83-90.

Md. Asaduzzaman, Ikeda, D., Kader, Md.A., Kinoshita, S., Abd Ghaffar, M., \& Abol-Munafi, A.B. (2017). Cellular muscle growth and molecular cloning and expression of growthrelated gene of Malaysian Mahseer Tor tambroides larvae fed with live and formulated feeds in indoor nursery rearing system, Aquaculture Reports, 5, 1-9.

Megeney, L.A., \& Rudnicki, M.A. (1995). Determination versus differentiation and the MyoD family of transcription factors. Biochem. Cell Biol, 73, 723-732. https://doi.org/10.1139/o95-080.

Men, K., Ai, Q., Mai, K., Xu, W., Zhang, Y., \& Zhou, H. (2014). Effects of dietary corn gluten meal on growth, digestion and protein metabolism in relation to IGF-I gene expression of Japanese seabass, Lateolabrax japonicus. Aquaculture, 428-429, 303-309.

Montero, D., Robaina, M.J., Caballero, R., Gines, R., \& Izquierdo, M.S. (2005). Growth, feed utilization and flesh quality of European sea bass (Dicentrarchus labrax) fed diets containing vegetable oils: a time-course study on the effect of a re-feeding period with a $100 \%$ fish oil diet. Aquaculture, 248, 121-134.

Moyle, P.B., \& Cech, J.J. (1982) In: Fishes: An introduction to Icthyology. Prentice-Hall International, Inc., London.

Musaro, A., McCullagh, K.J., Naya, F.J., Olson, E.N., \& Rosenthal, N. (1999). IGF-I induces skeletal myocyte hypertrophy through calcineurin in association with GATA-2 and NF-ATcl. Nature, 400, 581-585. 
Naya, F.J, \& Olson, E. (1999). MEF2: a transcriptional target for signaling pathways controlling skeletal muscle growth and differentiation. Curr Opin Cell Biol. 11, 683-688.

Ono, Y., Ojima, K., Shinkai-Ouchi, F., Hata, S., \& Sorimachi, H. (2016). An eccentric calpain, CAPN3/p94/calpain-3. Biochimie, 122, 169-187.

Pagano, M., Tam, S.W., Theodoras, A.M., Beer, R.P., Del, S.G., Chau, V., Yew, P.R., Draetta, G.F., \& Rolfe, M. (1995). Role of the ubiquitin-proteasome pathway in regulating abundance of the cyclin-dependent kinase inhibitor p27. Science, 269, 682-685.

Perez-Velazquez, M., Gatlin, D.M., González-Félix, M.L., García-Ortega, A., de Cruz, C.R., Juárez-Gómez, M.L., \& Chen K. (2019). Effect of fishmeal and fish oil replacement by algal meals on biological performance and fatty acid profile of hybrid striped bass (Morone crhysops $\$ \times M$. saxatilis $\left.\sigma^{7}\right)$. Aquaculture, 507, 83-90. https://doi.org/10.1016/j.aquaculture.2019.04.011.

Picha, M.E., Turano, M.J., Tipsmark, C.K., \& Borski, R.J. (2008). Regulation of endocrine and paracrine sources of Igfs and Gh receptor during compensatory growth in hybrid striped bass (Morone chrysops $\times$ Morone saxatilis). Journal of Endocrinology, 199, 81-94.

Preziosa, E., Liu, S., Terova, G., Gao, X., Liu, H., Kucuktas, H., Terhune, J., \& Liu, Z. (2013). Effect of Nutrient Restriction and Re-Feeding on Calpain Family Genes in Skeletal Muscle of Channel Catfish (Ictalurus punctatus). PLoS One. 2013;8(3): e59404. https://doi.org/10.1371/journal.pone.0059404

Reinecke, M., Schmid., A., Ermatinger, R., \& Loffing-Cueni, D. (1997). Insulin-like growth factor $I$ in the teleost Oreochromis mossambicus the tilapia: Gene sequence, tissue expression, and cellular localization. Endocrinology. 138, 3613-3619. https://doi: 10.1210/endo.138.9.5375.

Rowlerson, A., \& Veggetti, A. (2001). Cellular mechanisms of post-embryonic muscle growth in aquaculture species. In: Johnston, I.A. (Ed.), Fish Physiology, Muscle Development and Growth, vol. 18. Academic Press, London, pp. 103-140. https:// doi.org/10.1016/s15465098(01)18006-4.

Salem, M., Yao, J., Rexroad, C. (2005) Characterization of calpastatin gene in fish: its potential role in muscle growth and fillet quality, Comp. Biochem. Physiol. B,141, 488-497.

Sargent, J.R., Torcher, D.R., \& Bell, J.G. (2002). The lipids. Fish Nutrition 3, Hardy, R.W (Eds), Fish Nutrition, 3rd Edn, Academic Press, San Diego, pp. 181-257

Stickland, N.C. (1983). Growth and development of muscle fibres in the rainbow trout (Salmo gairdneri). J. Anat. 137, 323-333

Takakuwa, F., Fukada, H., Hosokawa, H., \& Masumoto, T. (2006). Availability of poultry byproduct meal as an alternative protein source for fish meal in diet for greater amberjack (Seriola dumerili). J. Aquac. Feed. Sci. Nutr. 54 (4), 473-480.

Tan, X., Hoang, L., \& Du, S. (2002). Characterization of muscleregulatory genes, Myf5 and myogenin, from striped bass and promoter analysis of muscle-specific expression. Mar Biotechnol, 4(6), 537-45.

Temm-Grove, C.J., Wert, D., Thompson, V.F., Allen, R.E., \& Goll, D.E. (1999) Experimental Cell Res. 247, 293 - 303.

Temple, G.K., Cole, N.J., \& Johnston, I.A. (2001). Embryonic temperature and the relative timing of muscle-specific genes during development in herring (Clupea harengus
L.). J. Exp. Biol. 204, 3629-3637.

Terova, G., Rimoldi, S., Chini, V., Gornati, R., Bernardini, G., \&Saroglia, M. (2007), Cloning and expression analysis of insulin-like growth factor I and II in liver and muscle of sea bass (Dicentrarchus labrax, L.) during long-term fasting and refeeding. Journal of Fish Biology, 70, 219233.

Tokumoto, T., Tokumoto, M., Seto, K., Horiguchi, R., Nagahama, Y., Yamada, S., Ishikawa, K., \& Lohka, M.J. (1999). Disappearance of a Novel Protein Component of the 26S Proteasome during Xenopus Oocyte Maturation. Experimental Cell Research, 247(2), 313-319. https://doi.org/10.1006/excr.1998.4357.

Tokumoto, T., Yamashita, M., Tokumoto, M., Katsu, Y., Horiguchi, R., Kajiura, H., \& Nagahama, Y. (1997). Initiation of Cyclin B Degradation by the 26S Proteasome upon Egg Activation. J. Cell Biol, 138, 1313:1322.

Tu, Y., Xie, S., Han, D., Yang, Y., Jin, J., Zhu, X. (2015). Dietary arginine requirement for gibel carp (Carassis auratus gibelio var. CAS III) reduces with fish size from $50 \mathrm{~g}$ to $150 \mathrm{~g}$ associated with modulation of genes involved in TOR signaling pathway. Aquaculture, 449, 37-47. https://doi.org/10.1016/j.aquaculture.2015.02.031.

Ulloa, P.E., Pena, A.A., Lizama, C.D., Araneda, C., Iturra, P., Neira, R., \& Medrano, F. (2013). Growth Response and Expression of Muscle Growth-Related Candidate Genes in Adult Zebrafish Fed Plant and Fishmeal Protein-Based Diets. Zebrafish, 10(1), 99-109. https://doi.org/10.1089/zeb.2012.0823

Valente, L.M.P., Cabral, E.M., Sousa, V., Cunha, L.M., Jorge M.O.F. (2015). Plant protein blends in diets for Senegalese sole affect skeletal muscle growth, flesh texture and the expression of related genes, Aquaculture, 453, 77-85, https://doi: 10.1016/j.aquaculture.2015.11.034

Watabe S. (2001). Myogenic regulatory factors. Fish Physiol, 24, 19-41.

Watson, A. M., Barrows, F. T., \& Place, A. R. (2013). Taurine supplemented plant protein based diets with alternative lipid sources for juvenile gilthead sea bream, Sparus aurata. Journal of Fisheries and Aquaculture, 4(1), 59-66.

Weatherley, A.H., \& Gill, H.S. (1984). Growth dynamics of white myotomal muscle fibres in the bluntnose minnow, Pimephales notatus Rafinesque, and comparison with rainbow trout, Salmo gairdneri Richardson. J. Fish Biol. 25, 13-24

Weatherley, A.H., Gill, H.S., \& Lobo, A.F. (1988) Recruitment and maximal diameter of axial muscle fibres in teleosts and their relationship to somatic growth and ultimate size. J. Fish Biol. 33, 851-859

Weatherley, A.H., Gill, H.S., \& Rogers, C.S. (1979). Growth dynamics of muscle fibres, dry weight, and condition in relation to somatic growth rate in yearling rainbow trout (Salmo gairdneri). Canadian Journal of Zoology 57, 23852392

Xu, C., Liu, W., Zhang, D., Liu, J., Zheng., X., Zhang., C., Yao., J., Zhu., C., \& Chi, C. (2020). Effects of partial fish meal replacement with two fermented soybean meals on the growth of and protein metabolism in the Chinese mitten crab (Eriocheir sinensis). Aquaculture Reports, 17, 100328.

Yasuda, Y., Kaleta, J., \& Bromme, D. (2005). The role of cathepsins in osteoporosis and arthritis: Rationale for the design of new therapeutics. Adv. Drug Deliv. Rev. 57, 973-993. 
Zhang, X., Sun, Z., Cai, J., Wang, J., Wang, G., Zhu, Z., \& Cao, F. (2020). Effects of dietary fish meal replacement by fermented moringa (Moringa oleifera Lam.) leaves on growth performance, non specific immunity and disease resistance against Aeromonas hydrophila in juvenile gibel carp (Carassius auratus gibelio var. CAS III). Fish \& Shellfish Immunology, 102, 430-439.
Ziman, M.R., Thomas M., Jacobsen, P., \& Beazley, L. (2001). A Key Role for Pax 7 Transcripts in Determination of Muscle and Nerve Cells. Experimental Cell Research, 268(2), 220-229. https://doi.org/10.1006/excr.2001.5282. 